研究論文 大学における ESD推進の可能性と課題

一「戦略的環境リーダー育成拠点形成事業」の検証からー

\author{
二ノ宮リムさち \\ 東京農工大学
}

Possibilities and Issues for Promoting ESD in Universities
- Based on Analysis of "International Environment Leaders Training Program" in Japan -

\author{
Sachi Ninomiya-Lim \\ Tokyo University of Agriculture and Technology \\ （受理日 2014 年 6 月 7 日）
}

This paper discusses possibilities and issues for promoting education for sustainable development (ESD) in universities, based on a study of the "International Environment Leaders Training Program” in Japan. The program, implemented by Ministry of Education, Culture, Sports, Science and Technology, has financed seventeen universities throughout the country to establish an environmental leadership education system and curriculum for post-graduate ESD since 2008. The paper analyzes the reports of these universities to identify problems and achievements for their organization structures to promote the all-campus and continued efforts, and for their educational practices to satisfy the major characteristics required for ESD. As a result, four key points for promoting ESD in universities emerge. First, it is important to facilitate the collective understanding and vision-building for ESD among stakeholders such as faculty members through promoting their collaboration in actual practices. Second, the transformation of existing degree course curricula toward ESD is indispensable while the mere introduction of an add-on ESD program often leads to conflicts between the existing course and the new program. Third, it is important to highlight diversities and connections among different local realities to relate learning to each student' $s$ reality. Finally, ESD in universities should promote mutual learning among people with diverse backgrounds such as disciplines, countries, and generations, which facilitate the development of values for sustainability in each learner.

Key words: ESD, education for sustainable development, higher education, university

\section{I はじめに}

「国連・持続可能な開発のための教育 $(\mathrm{ESD})$ の 10 年」(2005-2014年) 終了を前に、ESDの具 体的実践は試行錯誤の段階にあり、重要な推進主
体として注目されてきた高等教育機関においても (Corcoran and Wals 2004) ESDの主流化は実現 していない (Tilbury 2012)。

ESD推進が政策の影響を強く受けてきたとい われる日本では（野村ら 2010）、「ESDの10年」

問い合わせ先 sachininolim@gmail.com 
国内実施計画（2011年改訂版）(1)において教育機 関の重点的取組 4 項目のうち 3 つに大学の取組が 挙げられ、高等教育、特に大学の ESDが重視さ れている。これら政策的取組にもとづく実践が広 がる中、一方で、国内の高等教育における ESD に関する研究は著しく不足していることが指摘さ れ、「ESDの10年」後へ向け、実践を検証する研 究の進展が求められている（野村ら 2010）。

そこで本稿は、上記重点的取組の一つである文 部科学省（以下、文科省）「戦略的環境リーダー 育成拠点形成事業」における実践を検証しつつ、 大学の ESD推進へ向けた可能性と課題を論じる。

\section{II 研究の背景と枠組}

\section{1 持続可能性へ向けた高等教育機関の取組と ESD一国際的議論と動向}

持続可能性 (2)へ向けた高等教育機関の取組につ いては、1972年の国連人間環境会議がその重要 性を指摘し（Tilbury 2012)、1980年代にかけて 環境問題への関心向上とともに期待と議論が広 がった。1990年代からは、取組の推進を謳う国 際宣言や憲章が次々と採択され、Association of University Leaders for a Sustainable Future (ULSF)、Global Higher Education for Sustainability Partnership (GHESP)、Global Universities Partnership on Environment for Sustainability (GUPES)、Promotion of Sustainability in Postgraduate Education and Research (ProSPER.Net) 等、国際的連携が発達

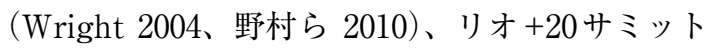
でも「高等教育による持続可能性イニシアティ ブ」が設立された。これらを通じ、教育、研究、 社会貢献、組織運営を含む高等教育機関の諸活動 における持続可能性へ向けた取組について議論が 発展したが、ULSFが2000年に創刊した国際学術 誌、International Journal of Sustainability in Higher Educationの 2001-2010年の掲載論文を分析した Wals・Blewitt（2010）によると、当初は大学の 省エネやごみ減量といった環境管理活動に関する 議論が主だったが、次第に教育や学習のあり方、 つまり ESDに関する議論が増えている。
一方で、高等教育におけるESDの実現には、 教育の内容や方法にくわえ、それを支えるシステ ムや、それと密接に関係する研究、組織運営、社 会貢献・連携における変革が必要であることも指 摘されてきた。2012年に国際的連携体制の一つ Global University Network for Innovation (GUNi)が発表した高等教育機関による持続可能 性へ向けた取組を概観する研究報告書の冒頭で も、持続可能性の実現には現代社会の発展モデル とそれを支える価值観を変革し新たな文化を創出 する必要があり、ESDの実現には既存モデルの 中で形作られた現在の教育システムについて、現 実理解や知のあり方に対する認識、知を社会と共 有する方法といった観点から見直さねばならない ことが述べられている（Escrigas 2012）。

しかし、このように議論が進展する一方で、実 践面では、前述の環境管理活動や持続可能性に関 する科目開設といった部分的取組が大半で、世界 の高等教育機関において持続可能性へ向けた取組 が主流化する状況はない（Tilbury 2012）。 Granados-Sanchezら（2012）は、各地の高等教 育関係者の意見から、主流化を阻む要因として、 分野間連携 - 学際的取組の難しさ、持続可能性が 単に「教育へ追加する一項目」ととらえられてい る現状、政府や上層部のビジョンと関係者間の理 解共有の不足があり、対策として、教員・学生 · 外部者の対話によるビジョン構築、学際的取組を 推進する制度改革、地域を巻き込んだ持続可能性 の文化の形成、全教職員への研修やカリキュラム の計画と実践が挙げられることを報告している。

\section{2 国内の高等教育における ESD}

$\lceil\mathrm{ESD}$ の 10 年」の提案国である日本は、ESDが 世界的に認知される契機をつくったとして評価さ れ (Ryanら 2010、Tilbury 2012)、その国の高 等教育機関には推進拠点としての期待が寄せられ てきた（日本学術会議環境学委員会環境思想・環 境教育分科会 2008)。国内の高等教育における $\mathrm{ESD}$ は世界の中でも活発であり、政策の影響を 強く受けているといわれる（阿部 2009, 野村ら 2010、Nomura ・ Abe 2010)。 
日本政府が 2006 年に発表した「ESDの 10 年」 国内実施計画初版の中で高等教育における重点的 取組事項とされた文科省「現代的教育ニーズ取組 支援プログラム（現代 GP）」では、2006-2007年度、 公募テーマの一つに「持続可能な社会につながる 環境教育の推進」を掲げて 30 件を採択し(3)、この 採択大学が中心となって設立した高等教育 ESD ネットワーク（HESD）は2007年から毎年フォー ラムを開催している。また、同じく重点的取組事 項とされ、文科省が支援してきた「サステイナビ リティ学連携研究機構（IR3S）」は、2005年に東 京大学に設置され、他大学等も連携し持続可能性 の実現へ向けた研究と教育を推進してきた (Komiyamaら 2011)。さらに、同国内実施計画 2011 年改訂版 ${ }^{(1)}$ で重点的取組とされた環境省「ア ジア環境人材育成イニシアティブ推進事業」と文 科省「戦略的環境リーダー育成拠点形成事業」は、 それぞれ政策根拠や目的、予算規模、実施大学数 等に異なる特徵を持ちつつ、いずれも大学の環境 人材育成プログラムを推進し、 $\mathrm{ESD}$ の具体的な 実践を形作ってきた（表 1 )。

こうして政策にもとづく大学の ESDが活発化 する一方で、国内の高等教育における ESDに関 する研究は極めて限定的であることが指摘されて いるが（野村ら 2010）、これら事業の実践当事者 らによる議論の蓄積もみられる。例えば、現代 GPを実施した岩手大学の比屋根（2009）は、 ESD は理解しにくいという学内の教員らの声に 直面し、具体像を「対話」の重要性という点から 示した。現代GPにおける実践事例を紹介し高等 教育における ESDを論じる試みもある（阿部・ 荻原 2011)。また、環境省・文科省環境人材育成 事業の関係者からは、講義、議論、発表、実習等 を通じた総合的な教育実践に関する多様な側面か らの論考が発表されている（中川2010、 Tamura・Uegaki 2012、二ノ宮リム 2013a、二 ノ宮リムら 2013、Mino・Hanaki 2013)。さらに 両事業関係者に他大学、企業、行政等も加わり環 境人材育成研究に関する交流も促進されている (表 1 参照)。こうして実践に伴う研究的進展もみ られるが、現段階では特定の実践に関する報告の
表 1 : 文科省・環境省による環境人材育成事業 (公募要領等をもとに筆者作成)

\begin{tabular}{|c|c|c|}
\hline & 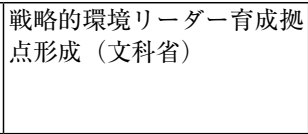 & $\begin{array}{l}\text { アジア環境人材育成イニシ } \\
\text { アティブ：環境人材育成の } \\
\text { ための大学教育開発事業 } \\
\text { (環境省 })\end{array}$ \\
\hline 公募 & $2008-2010$ 年度 & 2008-2009 年度 \\
\hline $\begin{array}{l}\text { 実施 } \\
\text { 期間 }\end{array}$ & $\begin{array}{l}\text { 各機関 } 5 \text { 年間（3 年目に中 } \\
\text { 間評価） }\end{array}$ & $\begin{array}{l}\text { 各機関 } 1 \text { 年間 (開発) また } \\
\text { は } 2-3 \text { 年間 (開発・実証) }\end{array}$ \\
\hline 採択数 & 17 大学 & 11 大学 \\
\hline 予算額 & $\begin{array}{l}\text { 各機関、年 間 } 7 \text { 千万 }-1 \text { 億 } \\
\text { 円を上限 }\end{array}$ & $\begin{array}{l}\begin{array}{l}\text { 各機関、年間 } 1 \text { 千万円を上 } \\
\text { 限 }\end{array} \\
\end{array}$ \\
\hline 根拠 & $\begin{array}{l}\text { 長期戦略指針「イノベー } \\
\text { ショョ } 25 」\left({ }^{(4)}\right. \\
\text { 総合科学技術会議「科学技 } \\
\text { 術外交の強化に向けて」 }\end{array}$ & $\begin{array}{l}21 \text { 世紀環境立国戦略 } \\
\text { 長期戦略指針「イノベー } \\
\text { ショョン 25」 }\end{array}$ \\
\hline 目的 & $\begin{array}{l}\text { 途上国における環境問題の } \\
\text { 解決に向けたリーダーシッ } \\
\text { プを発揮する人材（環境 } \\
\text { リーダー）を育成する拠点 } \\
\text { (プログラムと運営体制) } \\
\text { を形成 }\end{array}$ & $\begin{array}{l}\text { 各人の専門性を生かした } \\
\text { キャリア、市民活動等を通 } \\
\text { じて持続可能な社会づくり } \\
\text { に取り組む人材 (環境人材) } \\
\text { を育成するプログラムを開 } \\
\text { 発・実証 }\end{array}$ \\
\hline 対象 & $\begin{array}{l}\text { 大学院教育（アジア・アフ } \\
\text { リカカ等からの留学生受入を } \\
\text { 重視） }\end{array}$ & 大学学部・大学院教育 \\
\hline 言語 & 主に英語 & 主に日本語 \\
\hline $\begin{array}{l}\text { 両事業 } \\
\text { の交流 }\end{array}$ & \multicolumn{2}{|c|}{$\begin{array}{l}2008 \text { 年より不定期で両事業採択大学の会合を開催。 } \\
2011 \text { 年度から環境省事業により発足した環境人材育成 } \\
\text { コンソーシアム (EcoLeaD) が「環境人材育成研究交 } \\
\text { 流大会」を毎年開催、両事業採択大学を中心に他機関 } \\
\text { も参加。 }\end{array}$} \\
\hline
\end{tabular}

域を出ない論考も多く含まれ、研究成果の蓄積は 依然今後の重要な課題である。

また実践としても、これら事業による取組は国 内の高等教育全体の一部に過ぎない。高等教育に 限らず実践者の間には、国際的議論に伴い政策主 導で推進され「教育実践と離れた場所で企画され トップダウンで現場に導入された（原田 2009）」 ESDに対する懐疑的な見方もある中（二ノ宮リ ム 2013b)、現場の具体的取組を検証し可能性と 課題を明らかにすることは、実践にもとづくボト ムアップの ESD実現につながる。国内の高等教 育の持続可能性へ向けた変革の進展へ向け、これ ら事業における各大学の実践と政策を検証し、議 論を関係者間で共有していく必要がある。

\section{ESD とは何か}

ESDの実現には、教育に持続可能性に関する 知識やメッセージを部分的に取り入れるだけでな 
表 2：ESDに求められる主な特性に関する整理

\begin{tabular}{|c|c|c|c|}
\hline ESD の特性 & $\begin{array}{l}\text { ESD の } 10 \text { 年国際実施計画に示され } \\
\text { た ESD の特長 (UNESCO 2005(佐藤・ } \\
\text { 阿部監訳 2006)) }\end{array}$ & $\begin{array}{l}\text { 国内ネットワークによ } \\
\text { るテキストに示された } \\
\text { ESD における「学びの } \\
\text { 方法」(ESD-J 2009) }\end{array}$ & 左記文書や先行研究等における議論 \\
\hline $\begin{array}{l}\text { 持続可能性 } \\
\text { の価值 観・ } \\
\text { 概念への立 } \\
\text { 脚と創造 }\end{array}$ & $\begin{array}{l}\text { - 持続可能な開発の基礎となる原則 } \\
\text { と価值観に基づく } \\
\text { ・変化していく持続可能性という概 } \\
\text { 念の本質に対応していく }\end{array}$ & & 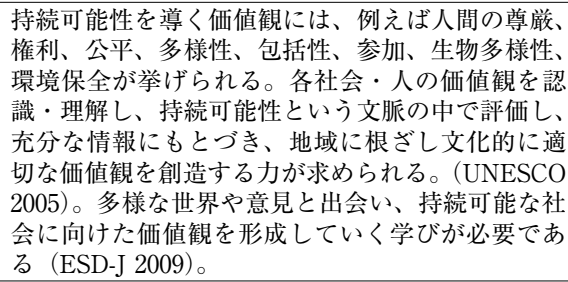 \\
\hline $\begin{array}{l}\text { 分野横断· } \\
\text { 学際性 }\end{array}$ & $\begin{array}{l}\text { ・学際的である。ESD は } 1 \text { つの学問 } \\
\text { 分野に収まるものではなく、あら } \\
\text { ゆる学問分野が ESD に貢献できる }\end{array}$ & & $\begin{array}{l}\text { 複雑な現実を持続可能性に関する多様な側面から } \\
\text { 理解し、分野や文化を越えて異なる価値観や知識 } \\
\text { と出会い、学習者が自らをふらええるために、学 } \\
\text { 際的な教育が必要である（UNESCO 2005・2006・ } \\
\text { 2012、Dam-Mieras 2006)。 }\end{array}$ \\
\hline $\begin{array}{l}\text { 学習者の主 } \\
\text { 体的参画 }\end{array}$ & $\begin{array}{l}\text { ・参加型学習および高次元の思考技 } \\
\text { 能を育むさまざまな教育方法を活 } \\
\text { 用する }\end{array}$ & $\begin{array}{l}\text { ・学習者の主体性を尊 } \\
\text { 重する } \\
\text { ・参加体験型の手法が } \\
\text { 活かされている }\end{array}$ & $\begin{array}{l}\text { 学習者自身が学習に参画する意欲や意志を持ち } \\
\text { (Clover 1996, Fien \& Skoien 2002)、学習の必要性 } \\
\text { や目的の明確化、学習内容や方法について考える } \\
\text { プロセスをコントロ必要である } \\
\text { (Sauvé 1998)。 }\end{array}$ \\
\hline $\begin{array}{l}\text { 現実的課題 } \\
\text { に対する取 } \\
\text { 組の体験 }\end{array}$ & $\begin{array}{l}\text { ・環境、社会、経済という持続可能 } \\
\text { 性の } 3 \text { の領域すべてが健全な状 } \\
\text { 態であるように取り組みを行う } \\
\text { ・ ミュニティに基ゔたた意思決定、 } \\
\text { 社会的寛容、環境的責任、変化に } \\
\text { 適応できる労働力、生活の質とい } \\
\text { う課題に対処できる市民の能力を } \\
\text { 育成する }\end{array}$ & $\begin{array}{l}\text { ・ ほんもの体験を大切 } \\
\text { にしている } \\
\text { ・現実的課題に実践的 } \\
\text { に取組んでいる }\end{array}$ & 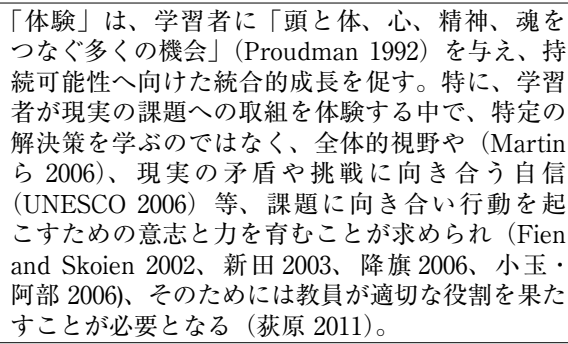 \\
\hline $\begin{array}{l}\text { 地域への根 } \\
\text { ざし }\end{array}$ & $\begin{array}{l}\text { ・地方に根ざし、文化的にも適切で } \\
\text { ある }\end{array}$ & $\begin{array}{l}\text { - 人や地域の可能性を } \\
\text { 活かしている } \\
\text { ・地域の自然・産業・ } \\
\text { 文化・歴史を掘り下 } \\
\text { げる }\end{array}$ & $\begin{array}{l}\text { 生活の場である地域と学習をつなげ、地域資源に } \\
\text { もとづ学びと、学んだ成果の地域での活用が求 } \\
\text { められる(UNESCO 2003)。それにより、人々は } \\
\text { 地域の特徵や問題点に気づき、地域づくりへの参 } \\
\text { 加意欲を高め(見上 2009)、持続可能な社会を担 } \\
\text { う主体として育つ(櫃本 2009)。ESDのあり方は } \\
\text { 地域の文脈によって異なることへの配慮も重要で } \\
\text { ある (Fien and Skoien 2002)。 }\end{array}$ \\
\hline $\begin{array}{l}\text { 地域と世界 } \\
\text { のつながり }\end{array}$ & $\begin{array}{l}\text { ・地方のニーズ、認識、状況に基づ } \\
\text { くが、地方のニーズを充たせば国 } \\
\text { 際レべルでもその影響が及ぶこと } \\
\text { が多いということも認識する } \\
\text { ・状況、世界的な問題、地方ごとの } \\
\text { 優先事項を考慮に入れて、教育の } \\
\text { 内容を検討する }\end{array}$ & & $\begin{array}{l}\text { グローバル社会においては、遠い国の問題に思 } \\
\text { えることも自らの暮らしと密接につながって拉 } \\
\text { り、問題を解決するためには持続不可能なつなが } \\
\text { りを持続可能なつながりに変えていくことが必要 } \\
\text { (ESD- } 2009 \text { 。学習者は、地域の諸課題と世界の } \\
\text { 課題群のつながり気づき、その視点をもって持 } \\
\text { 続可能な社会へ向けた行動に参画していく（小玉. } \\
\text { 阿部 2006)。 }\end{array}$ \\
\hline $\begin{array}{l}\text { 多様な教育 } \\
\text { 形態の連 } \\
\text { 携・継続的 } \\
\text { な学習機会 }\end{array}$ & $\begin{array}{l}\text { ・生涯学習を推進する } \\
\text { ・フォーマル、ンフォーマル、イ } \\
\text { ンフォーマル教育に取り組む }\end{array}$ & $\begin{array}{l}\text { ・継続的な学びのプロ } \\
\text { セスがある }\end{array}$ & $\begin{array}{l}\text { ESD における学習者には子どもも大人も含まれ } \\
\text { る。ESD は、持続可能な社会へ向けた課題に向き } \\
\text { 合い、社会を変革していく生涯学習として、 } \\
\text { 学校、大学、企業や行政の職員研修、社会教育講 } \\
\text { 座や市民活動（UNESCO 2005)、テレビ、新聞な } \\
\text { どのメディア（UNESCO 2005）等を含むあらゆる } \\
\text { 教育の場で実践される。 }\end{array}$ \\
\hline $\begin{array}{l}\text { 多様な立場 } \\
\text { の人々の学 } \\
\text { びあい }\end{array}$ & & $\begin{array}{l}\text { ・多様な立場・世代の } \\
\text { 人びとと学びあう } \\
\text { ・関わる人が互いに学 } \\
\text { び合う }\end{array}$ & $\begin{array}{l}\text { 相互学習を通じ、多様な思考、価値観や文化に触れ、 } \\
\text { 尊重し合う切さを理解しつつ、思を見 } \\
\text { つめ直し、持続可能性の課題について再検討する } \\
\text { ことが必要である (Marouli 2002、Kato 2002)。 } \\
\text { その中で、持続可能性の実現へ向けた集団の知識 } \\
\text { や価値観が育ち共有される (Stein \& Imel 2002)。 }\end{array}$ \\
\hline
\end{tabular}


く、教育目的や方法を含む総合的な変革が求めら れる（Tilbury・Cooke 2005）。では具体的にどの ような変革が必要か。これまで様々な実践と議論 を通じ、ESDに求められる特性が示されてきた。 表 2 に、中でも ESDの 10 年を推進するための基 本的枠組を示す国際実施計画（UNESCO 2005） と、国内の ESD推進において中心的役割を担う ESD-J（NPO法人「持続可能な開発のための教 育の 10 年」推進会議）によるテキスト（2009） に示されたリストから、項目をまとめ整理し、先 行研究における議論を付記した。これらは変革を 導く具体的視点となる。

\section{III 研究の目的・方法と対象事例}

\section{1 本研究の目的と意義}

本研究は、上記背景にもとづき、国内で政策的 に推進される大学の ESD 実践を検証し、実質的 なESDの実現につながる可能性と課題を論じる ことを目的とした。

本稿では、「ESDの 10 年」重点的取組事項とさ れた先述の環境人材育成事業のうち、文科省「戦 略的環境リーダー育成拠点形成事業」を検証対象 とした。表 2 でみたとおり、本事業は、環境省事 業に比べ、採択大学数、各大学予算額、事業実施 年数のいずれにおいても規模が大きい。また、本 事業は、採択大学に対し、教育プログラム開発と 同時に学内外の運営体制構築を求め、大学ごとの 包括的な取組を促してきた。これらの点から、本 事業は大学のESD進展により大きな影響を与え ることが期待され、実態を検討する必要性が高 い。

また、大学の「環境人材育成」には、教養教育 での「教養として環境に関する基礎的知識や理解 を持つ人材」の育成と、専門教育での「環境の知 識を各専門分野に取り入れて環境保全のために実 社会で行動する人材」の育成があり、行動を重視 するESDには後者の専門教育における取組がよ り重要であることが報告されており（高橋・吉沢 2008)、大学院教育に対象を絞る文科省事業に着 目することで、専門教育における ESD進展に焦 点を当てることができる。
本事業に対する検証としては、先述の実施大学 間会合や研究大会、論文等を通じ、成果や課題が 共有されているほか、科学技術振興機構が設置す る評価作業部会が各大学に対し実施 3 年度目と事 業終了後に評価を行っているが、これまで事業全 体を ESDの視点から検討する試みはみられない。 実質的な ESD 進展へ向けた検証が必要である。

そこで本稿は、文科省環境人材育成事業におけ る各大学の実践を ESDの視点から横断的に検討 することで、今後の大学における ESD 進展へ向 けた可能性と課題を提示する。

\section{2 本研究の方法}

上記を目的とした研究にあたり、公募要領(6)、 各採択大学の実施計画書や中間報告書(7)、2013年 9 月に開催され全採択大学が参加した「環境リー ダープログラム合同会議 2013」の発表及び発表 予稿集（筑波大学EDL事務局 2013）を中心に、 各大学のウェブサイト等も参照し、実践状況に関 する情報を収集した。その中から、本事業が単な る科目開設といった部分的取組に留まらず、 ESDの進展へ向けた变革に結びつく可能性を検 討するため、まず、実施組織体制の側面から、全 学的連携と実践継続へ向けた可能性と課題を検討 した。次に、教育実践の側面から、表 2 の「ESD に求められる主な特性」の実現について検討し た。その結果を踏まえ、本事業における実践が示 す大学の ESD 進展の可能性と課題を考察した。

\section{3 対象事例の概要}

文科省「戦略的環境リーダー育成拠点形成事 業」は、2007年に総合科学技術会議の有識者議 員により発表された「科学技術外交の強化に向け て」(6)と、同年に閣議決定された長期戦略指針「イ ノベーション $25 」$ (7)にもとづき翌 2008 年度に開 始された。前者は、外交と科学技術を連携させ推 進する「科学技術外交」の概念を提示する中で「具 体的に取り組むべき課題」の一つに「世界の環境 リーダーの育成」を挙げ、開発途上国（以下、途 上国）との科学技術協力の一環として留学生に日 本の環境技術や政策を学ぶ機会を提供する必要性 
を謳い、後者は 2025 年までの日本に必要な短〜 中長期的政策を示す中で「早急に取り組むべき課 題」に、「大学改革」の一環としての「世界に開 かれた大学づくり」と、「環境・エネルギー等日 本の科学技術力による成長と国際貢献」の一環と しての「世界の環境リーダーの育成」を掲げた。 つまり本事業は当初、主に外交や国際協力の一環 として構想され、必ずしも ESDへ向けた大学教 育変革を目的の主軸に据えたものではなかった。

しかしながら公募の段階では、機関の長が率い る戦略的体制のもと、途上国の課題解決に向けた 人材育成システムを構築し、国内外の大学院生が 日本の環境技術・政策をともに学ぶための「環境 リーダー育成プログラム (以下プログラム)」を 策定・実施する取組を支援するとし、新科目の導 入に留まらず、システ

ムとプログラム構築へ の全学的取組を求め た。また、プログラム において重視すべき点 として、国内外学生間 の交流、多専門分野の 横断的履修、インター ンシップ等の実践的学 習、修了生のネット ワークを挙げ、前章の 「ESDに求められる特 性」との合致がみられ る。

こうした背景のも と、17大学が採択され (表 3 )、全大学が事業 終了を迎える2014年度 末までに千人以上の修

表 3：戦略的環境リー ダ一育成拠点形成事業 採択大学（「記号」は本 稿IV章で用いるために 筆者が設定)

\begin{tabular}{|c|c|c|}
\hline $\begin{array}{l}\text { 採 } \\
\text { 伬 }\end{array}$ & 記 & 大学名 \\
\hline \multirow{5}{*}{$\begin{array}{l}\frac{12 x}{14} \\
\frac{10}{4} \\
\& \\
\infty\end{array}$} & A & 広島大学 \\
\hline & $\mathrm{B}$ & 京都大学 \\
\hline & $\mathrm{C}$ & 名古屋大学 \\
\hline & $\mathrm{D}$ & 早稲田大学 \\
\hline & $\mathrm{E}$ & 東京大学 \\
\hline \multirow{7}{*}{$\begin{array}{l}\frac{10 x}{14} \\
8 \\
8 \\
8\end{array}$} & $\mathrm{~F}$ & 筑波大学 \\
\hline & G & 神戸女学院大学 \\
\hline & $\mathrm{H}$ & 岐阜大学 \\
\hline & I & 北海道大学 \\
\hline & $\mathrm{J}$ & 横浜国立大学 \\
\hline & $\mathrm{K}$ & 東京農工大学 \\
\hline & $\mathrm{L}$ & 北九州市立大学 \\
\hline \multirow{5}{*}{ 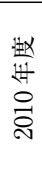 } & $\mathrm{M}$ & 九州大学 \\
\hline & $\mathrm{N}$ & 静岡大学 \\
\hline & $\mathrm{O}$ & 慶應義塾大学 \\
\hline & $\mathrm{P}$ & 熊本大学 \\
\hline & $\mathrm{Q}$ & 東北大学 \\
\hline
\end{tabular}
了生輩出が見込まれる（辻村 2013）。

\section{N 結果}

以下、17大学の実践について、実施組織体制 と教育実践の各側面から、ESD 進展へ向けた可 能性や課題を示す事項を整理する。特定の事例を 参照する場合は、表 3 「記号」で該当大学を示す。

\section{1 実施組織体制にみる可能性と課題一全学的連 \\ 携と実践継続へ向けて}

先述のとおり、大学の ESD推進には、既存教 育の変革へ向けた全学的連携・学際的取組が必要 である。本事業は、各大学に、機関長が率いる運 営体制を通じた教育システムの構築と、継続的運 営を可能にする組織改革を求めている。各大学は これに従い学長等を統括責任者とする運営体制を 構築しているが、実際に全学的連携が進み取組が 継続する可能性については、検証が必要である。

事業の組織体制を実施主体と対象学生の双方か らみると、大半の大学 (14大学) で特定の教育 組織 (一つまたは複数の連携する研究科・学府等) が実施主体としてプログラムを担い、またその大 半（12大学）で同組織の学生のみをプログラム の対象としている (残り 2 大学は、それぞれ他組 織を含む複数組織または全学の学生を対象)。一 方、3 大学で、各部局から独立した既存または新 設の全学横断組織が実施主体となり、全学の学生 を実施対象としている。また、全大学において、 実際の履修者は対象のうち希望して選考を経た一 部の学生である。

大半の大学が採用する、特定の既存組織・学生 を実施主体・対象とする体制下では、関係者が認 識を共有しやすく、また事業の有無が組織継続に 与える影響が小さく、取組継続が期待できるが、 全学的な連携の広がりには欠ける。一方、全学横 断組織を実施主体とし全学の学生を対象とする体 制下では、全学的連携の実現は当該組織の構成員 や権限、ビジョンや理解の共有状況に左右され、 当該組織の運営に必要な予算が恒久化されていな ければ事業終了と同時に組織と取組が縮小・停止 される可能性が高まる。

事業終了後の予算確保は、既存組織が実施を担 う場合も含め、実践の継続に大きな影響を与える 要素である。終了大学からは、補助金による教職 員雇用の打切りに伴い、他の教職員に過度な負担 が生じたり、事業が設置した講義や演習を縮小。 廃止したりという状況が報告されている。これに 対し、大学立地自治体等との共同設立団体や関連 教員が設立したベンチャー企業を受け血に、企業 
との共同研究資金等を得て人材を雇用し、教育体 制の持続を実現した事例が報告されている（D）。

一方で、事業成果の全学的広がりや継続の可能 性として、「将来的には対象研究科の学生全てが 履修できるよう研究科の修了要件を見直し、研究 科全体の教育改革を目指す（D)」、「事業を通じ て学際的・国際的な環境教育プログラムの重要性 に対する認識が実施を担った研究科内で共有され 全体の方向性として取組まれるようになった (F)」、「事業を通じ構築した分野横断型の実践的 教育や国際的教育を全学展開するための調整が始 まり事業に全学の多くの教員が組織的に参加した ことがさらなる学際的教育プログラムの構築にも つながっている（A）」、「実践的なリーダー育成 の全学的実現へ向けたモデルとなった（D)」と いった報告がみられる。

\section{2 教育実践にみる可能性と課題一「ESDの特 性」の実現}

1 ）持続可能性の価值観・概念への立脚と創造 本事業の公募要領には「我が国の優れた環境技 術や政策」を習得しそれをもって途上国の環境問 題の解決に貢献できる人材を育成するとあるが、 そうした技術や政策が基づくべき持続可能性概念 や価值観については言及がない。一方、「学生間 の活発な意見交換や交流の下、アジア地域等の環 境問題に対する認識を共有」することを求めてい る点については、学生が自身の価值観を形成して いくために必要となる、多様な考え方・価值観と の出会いを推進しているととらえることができ る。

各大学の報告にも、プログラムが着目する課題 は説明されていても、立脚する概念や価值観に関 する記述はほとんどみられないが、一方で、国内 外学生が意見を交換し合い議論する機会は全大学 で推進されている。その中では、ワークショップ を通じて「日本人学生と留学生が活発に議論を行 い、異なる視点や価值観、文化を互いに理解し、 国際的な視野を培う $(\mathrm{G})$ 」、海外インターンシッ プで現地の実務者との意見交換を通じ「環境問題 がいかに地域固有の特性や価值観等と密接に関係
しているかを理解する（L)」というように、異 なる価值観やそれと環境問題との関係への理解を 促す例や、さらに、海外拠点大学教員を含む多様 な講師によるオムニバス講義を通じて「画一なサ ステイナビリティ（持続性）の概念を提示するの ではなく‥受講生個々人が独自のサステナビリ ティについての概念、そして認識を築く（I）」と いうように各学生による概念・価值観の創造に意 識的に取り組む例が、少数だが報告されている。

\section{2 ）分野横断・学際性}

本事業は、公募要領に「環境に係る自然科学分 野と人文・社会科学分野をバランスよく履修し、 幅広い学識を修得するものであること」と記し、 教育の学際化を明確に求めている。これに対し、 ほぼ全ての実施大学が、必修の学際科目を設置し ている。その多くはプログラムのテーマに関する 基礎的知識を扱う導入科目だが、異なる分野の学 生が共同で研究や課題解決に取組む学際的演習科 目（A、O）もみられる。学位論文を多分野教員 が共同で指導する試みもあり、現実社会の課題を 学際的に探求する営みが促されている。また、異 なる分野の学生間の交流も各大学で重視されてい るが、議論や発表、国内外の合宿実習がそのため の場として重要な役割を果たしている。

一方、「プログラムで扱う内容と各学生の研究 内容が大きく異なる場合に、特に教員から学位課 程における学習や研究の支障となるという懸念が 表明され、学際的教育と専門教育・研究のバラン スに学生、指導教員、プログラム教員がそれぞれ

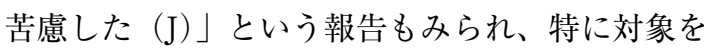
特定の教育組織の学生に限らない場合、学位課程 とプログラムが融合せず、専門教育と学際的教育 の連携が顕著な課題となっている。

\section{3) 学習者の主体的参画}

学生の主体的参画には、学生自身が学習の目 的、内容、方法等をコントロールでき、自身の経 験や知識と学習を関連づけられることが重要だ が、そのための機会として、各大学で、学生の意 見をプログラムに反映させるための質問紙・聞取 調査や、発表や議論を通じた主体的学習の促進、 実習やセミナー等の学生自身による計画と実施の 
ほか、「留学生が出身地域の環境問題を論文の テーマとして持参する $(\mathrm{F}) 」 「$ 学生向けの研究助 成制度を設置して応募から実施、報告まで自ら取 り組む経験を提供する（A、O)」という学位研 究の課題設定や実施における主体性促進の報告が みられる。一方で、「実習を学生主導で計画した いという声があっても集団研修では求める成果や 負担の程度が学生間で異なり難しい（L)」、「主 体的参画のために年間を通じたチーム活動がある とよいという学生の声に応じ実施したものの、多 様な専攻の学生が忙しさの合間を縫って協働する 難しさから、活動が停止してしまう場合がある (K)」といった、学習にともなう付加的負担に対 する学生間のニーズや意識の違いや、学位課程や 就職活動等との両立に関する難しさも報告されて いる。

\section{4 ）現実的課題に対する取組の体験}

本事業は、プログラムに実践的教育を取り入れ ることを求めており、全大学がインターンシップ やフィールド実習といった体験の機会を提供して いる。そこで、これらを「ただの体験」にしない ための現実的課題への取組について検討が必要で ある。各大学の報告には、例えば「訪問先地域で 廃棄物処理、生活用水供給といった特定の課題に 関する改善案の提案に取組む $(\mathrm{M}) 」 「$ 東北大震災 の被災地に教員と学生を派遣し復興案を策定する 取組をカリキュラムに組达む（O)」といった、 現実の具体的課題への探求と対策提案に集団で取 組む実践がみられる。また個別実習でも、「各学 生の専門性や関心に応じたテーマを設定しつつ現 場で具体的な課題を発掘し問題を理解する『問題 探求型』もしくは解決策を模索し提案する『問題 解決型』のインターンシップを実施する (C)」「各 学生の専門性と能力開発に適したテーマを設定し 受入先にも得るところのある『貢献型インターン シップ』に発展させている（D)」というょうに、 個々の関心や専門性を活かしつつ、実習地での具 体的な課題へ取組む実践が報告されている。

しかし、多くの大学で、現場体験に費やされる のは数週間程度と短く、現実的課題への取組は限 定的となる。その中で、研究よりも実践を重視し、
地元 NPO での 1 年間を通じた活動を課す事例 $(\mathrm{G})$ においては、「単なる体験から進んだ学生の主体 的な取り組みが実現している半面、国内学生は多 くが学位課程の学習や論文作成との両立が難しく プログラムを中退している」ことが報告されてい る。一方、国内・国外活動を組み合わせて修士 3 カ月間・博士 5 カ月間のインターン研修を課す事 例 (B)からは、特に海外での長期研修によって「現 実的課題に対する学生の『関心の目』が開き、解 決へ向け現実に即した学位研究につながってお り、現場体験を学位研究と結びつけることで各学 生の学位課程全体を通じた現実的課題への取組が 実現しているとともに、途上国での現実的課題に 対する教員の取組も促されている」ことが報告さ れている。

\section{5 ）地域への根ざし}

本事業における教育が根ざすべき地域には、主 に、大学立地地域等の、学生が現在暮らし学ぶ地 域と、アジア・アフリカ等の、修了後の学生が暮 らし働く地域がある。

前者の「現在暮らし学ぶ地域への根ざし」には、 「地域の環境污染克服の歴史や環境モデル都市と しての実績から学ぶ（L)」「代表的地下水都市の 大学として地元企業とも連携し地下水環境リー

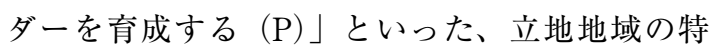
性にもとづく教育の設計と、「地元市民団体での インターンシップを通じ地域に根ざす活動の重要 性を学ぶ $(\mathrm{G}) 」 「 大$ 学周辺地域の自然環境を生か したカリキュラムを市民団体と連携して整備する (D)」といった、周辺地域の環境や活動を教育の 場として活かす取組がある。Dでは、地域の取組 を講義や視察で学び、農作業、里山保全等の活動 を体験し、現状を調査して、子ども向け環境学習 プログラムやケーブルテレビ番組制作に取り組む という必修演習科目が開設され、地域から学び地 域に貢献する中で育まれる取組や主体の有機的つ ながりや人間関係の感覚が、専門研究の素地とし ても有効であると報告されている。

「修了後に暮らし働く地域への根ざし」は、修 了生がアジア・アフリカ等をはじめとする様々な 地域で学習成果を生かすために重要だが、それに 
は主に 4 つのあり方がみられる。まず、「経済開 発を求める途上国地域の現状を理解し適切な対策 を考えるため、経済と環境の関連を重視した講義 や研究指導を実施 $(A \cdot J) 」 「$ 政情や科学技術の 状況から途上国の環境問題解決には最新技術・政 策の教授より地域に根ざす指導者の育成が必要と 考え、後者を主目的としたカリキュラムを構築 (G)」といった、日本と途上国地域の違いを意識 したプログラム設計である。次に、「途上国ニー ズにもとづく共同研究プロジェクトに学生が参画 (M)」「留学生が出身地域の環境問題を研究や学

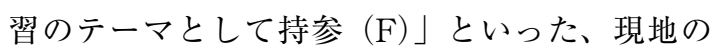
具体的ニーズを教育テーマに据える試みである。 三つ目に、「海外実習地で現地の社会ニーズや環 境問題に対峙しながら問題を見出し解決できる能 力を育成 $(\mathrm{B}) 」 「$ 海外実習先地域の行政関係者や 実務者と意見交換する機会を設け、環境問題が地 域固有の特性や価值観等と密接に関係しているこ とを理解し現地ニーズを把握 $(\mathrm{F}) 」$ というように、 環境問題や対策における地域性について体験を通 じ理解を促す取組である。最後に、「海外拠点教 員や学生による現地の地理・文化・地域知・言語 に関する講義を実施する（I）」という特定地域に 関する理解を深める取組がみられる。

\section{6 ）地域と世界のつながり}

「現在暮らし学ぶ地域」「将来暮らし働く地域」 に根ざす教育がそれぞれ試みられる中、それら二 つをつなげるためにも、地域の多様性を理解しつ つ関連性を認識し、地域（ローカル）を世界（グ ローバル）に位置付ける視点が重要となる。各大 学の報告にはこうした視点に関する記載は限定的 で、全体的に模索の段階にあるといえる。

例えば、「共通必修科目において国際的な視点 からみた環境問題と地域固有の問題への認識や対 応について講義する（B)」「アジアの提携大学や 国内・学内外の講師によるリレー講義を通じてア ジアと日本の環境問題への取組を国際的な視点か ら比較し地域に根ざしつつ複眼的な視点から討議 する $(\mathrm{G}) 」 「$ 海外実習の合同報告会で各実習地の 状況を比較し関連性を討議して俯瞰的視野を養う (K)」というような、国内外各地の状況を比較し
つつ世界的文脈に位置付ける試みがみられる。

\section{7 ）多様な教育形態の連携・継続的な学習機会}

本事業は「育成された環境リーダーと大学等と の密接な関係を継続するための活動」を求め、各 大学で、同空会の設立やインターネット (SNS 等) を介した交流、シンポジウムの開催のほか、国内 での短期研究留学や実習・ワークショップ (A・ $\mathrm{E} \cdot \mathrm{H})$ 、修了生母国でのセミナー (L) 等へ修了 生を受入れたり、修了生が州国後取組む課題に応 じた教育コースの提供 $(\mathrm{H})$ 、国外修了生との連 携による教育研究活動 $(\mathrm{B} \cdot \mathrm{F} \cdot \mathrm{N} \cdot \mathrm{O} \cdot \mathrm{P}$ 等 $)$ といっ た継続的な学習機会の提供を計画している。ま た、修了生が中心となって東北大震災復興支援拠 点を設立しプログラムの研究フィールドとしても 活用されている事例（D）もある。

しかし先述のとおり、事業終了後の予算廃止・ 縮小に伴い、多くの大学が現役学生に対するプロ グラムを縮小する中、修了生への教育機会は限定 的となる、または持続しない可能性も考えられ る。

継続的学習機会の提供については、修了生のみ ならず社会人一般を対象とすることも考えられ る。例えば学位課程と連動しない社会人向けの 「履修証明プログラム」を設置する試み（I）が報 告されており、企業や市民団体等との連携も含 め、社会人を対象としたプログラム提供により、 生涯学習としてのESDの進展に寄与できる可能 性がある。

\section{8 ）多様な立場の人々との学びあい}

本事業下では、「学際性」の項で論じたとおり 異分野の学生や教員間の相互学習が重視されてい るほか、行政・企業・民間団体等との協力や、採 択大学間の共同実習や合同会議等実施、博士課程 学生と修士課程学生との交流等、様々な関係者間 の学びあいが促進されている。

その中でも特に重視されているのが、国内学生 と国外学生の学びあいである。本事業は、対象者 として国外学生と国内学生の双方を含むこと、学 生間の活発な意見交換や交流が行われることを求 め、国内外学生の学びあいによる効果が十分に発 揮される内容となっているかを評価項目としてお 
り、全大学が留学生を積極的に受け入れ、国内外 学生間の相互学習を推進している。講義や議論、 グループワーク、集団実習等がそのための場とし て活用されており、「複数研究室の留学生と国内 学生の居室を合同化し日常的な交流を促進する (L)」という試みもみられる。

また、全大学が海外の大学等との協力関係を築 き、遠隔講義の共同実施、海外実習の指導協力、 海外現地学生に対する短期コース開講等を実施し ている。これらを通じ、「専門的内容と教育プロ グラムの立案・実施の双方に関し、実施大学と海 外大学の教員間の相互理解と協働が進み、今後の 研究と教育の展開につながる（E)」といった報 告があり、国内外の教員間の学びあいも促されて いる。

こうした学びあいを促進するために本事業にお けるプログラムはほぼ全て英語で実施されている が、英語での教育が国内外学生双方にとって大き な魅力となっている一方、英語教育についていけ ず中退する者が出ているという報告もみられる。

\section{$\mathrm{V}$ 考察一本事例が示す大学の ESD 推進へ向け た可能性と課題}

前章では、各大学の取組について、実施組織体 制面から全学的取組と継続について、教育実践面 から ESD特性の実現について、可能性や課題を 示す事項を整理した。その結果から浮かび上が る、大学の ESD 進展において鍵となる 4 つの観 点から、以下、可能性と課題を考察する。

\section{1 協㗢を通じた理解共有とビジョン構築}

まず、ESDへ向けた全学的取組の実現には、 どのような実施組織体制をとる場合も大学関係者 全体の理解共有とビジョン構築が鍵となり、それ は具体的実践における協働を通じて促される可能 性があることが示された。大半の大学が特定の組 織・学生を実施主体・対象とする中、全学横断組 織による実施や全学学生を対象とする事例もみら れたが、いずれも機関の一部における限定的取組 の段階にあることに変わりなく、事業終了後の全 学的展開や実践継続は共通の課題であった。本事
業の取組が全学的に発展、継続し、教育全体の改 革に発展するには、先述の Granados-Sanchez ら （2012）が指摘したように、教員・学生・外部者 の対話によるビジョン構築、学際的取組を推進す る制度改革、カリキュラムの計画と実践といった 全学的対策が必要となる。本事業では、学際的演 習科目や学位論文の共同指導といった、異なる分 野の学生と教員による協働実践や、事業に参画し た組織や教職員間に理解が広がり取組が発展する 様子が報告された。これは、事業を通じた具体的 実践における協働が、多様な関係者の理解共有と ビジョン形成へ向けた対話を促した様子を表して いるといえる。

同時に、実践が継続し取組が広がるにあたり、 事業終了後の予算確保が壁となることも改めて確 認された。自治体や企業との連携により組織と資 金・人材を確保した事例は他の参考になろう。一 方で、ESDが既存教育への追加ではなく既存教 育の変革であるならば、追加予算を必ずしも要さ ない。現状の教育のあり方と経費を見直し ESD へ向けて変革することこそが重要なのであり、そ のためにはやはり関係者の理解共有とビジョン形 成が必要となる。具体的実践を通じて理解とビ ジョンを共有した関係者が、既存の予算と教育の 中で実践を継続しながら他を巻き込み、対話を促 し、協力者・理解者を広げることができれば、全 学の制度改革と実践の可能性を生むであろう。

\section{2 既存学位課程の変革}

次に、本事業の実践からは、プログラムと学位 課程との連動・融合による学位課程そのものの変 勒重要であることが可能性、課題の両側面から 示された。「学生がプログラムへの積極的参加を 維持できない」「各学生の求める負担や成果のレ ベルが異なり学生主導型教育を進めにくい」「現 実の課題に取組む体験型教育に時間を割けない」 「学際的教育と専門的教育のバランスに学生も教 員も苦慮する」といった ESD特性の実現を阻む 問題の多くは、学位課程とプログラムが効果的に 連動していない結果である。一方で、「プログラ ムを通じ学位課程の教育・研究における学生の主 
体性を促進する」「学際的理解や実践を促す共通 科目で各学生の専門分野とプログラムの関連への 認識や分野間の協働を育む」「各学生の関心や専 門を活かしながら現実の課題に取組む」「現場の 具体的課題を学位研究のテーマとする」「体験を 通じて得た地域に根ざす感覚を学位研究に役立て る」「学位研究指導を多分野教員が連携して行う」 といった、学位課程とプログラムが効果的に連動 し ESD特性の実現につながる実践も多数みられ た。これらは大学におけるESD推進の大きなヒ ントとなる。

\section{3 「地域」の多様性と関連性への認識}

三点目として、大学のESDにおいては地域の 多様性と関連性を理解し、教育と「現在暮らす。 学ぶ地域」「将来暮らす・働く地域」をつなぐ努 力が重要になることが示された。「地域へ根ざす」 ことはESDの重要な特性だが、学生が各地から 集まり各地に出ていく高等教育、特に本事業のよ うな国際プログラムにおいて、学生の関わる地域 は非常に多様である。そこで、各学生が関わる地 域を学びと関連づけつつ、地域の多様性と共通 性、関係性を意識化することが必要となる。本事 例には、多様な地域のあり方を意識した講義や指 導、各学生が関わる地域の具体的ニーズにもとづ く教育や研究、実習地と自身の関わる地域との相 違・共通点や関係性に関する議論、といった方策 がみられ、他の参考になろう。地域の多様性と関 係性の理解は、地域を世界に位置づける視点にも つながる。さらに、学生が、自身が関わる地域を 起点に学習の意義を認識できれば、学習に対する 主体的参画が促されるとともに、学習が現実の課 題と結び付き行動につながるのである。

\section{4 分野と国境を越えた学びあいの促進による 「価値観」の創造}

最後に、大学のESDにおける分野や国境、世 代を越えた学生や教員の学びあいの中で、各人が 持続可能性へ向けた価值観を創造することの重要 性と可能性に着目したい。本事業では、国内外の 学生と教員が意見や知識を持ち寄り互いに成長す
る相互学習が推進されていた。また、学位取得と 連動しない社会人向けプログラムの事例等、社会 人教育の促進もみられた。多様な背景を持つ学生 がともに学べる場として大学が機能すれば、相互 学習と継続的学習の双方を実現し、各人の持続可 能性へ向けた価值観の創造を支える。大学は、多 様な学習者が出会い学びあいながら価值観を形成 する場として、大きな可能性を持つのだといえ る。

なお、国際的相互学習において英語をはじめと する外国語は重要なツールとなるが、言語能力が 学習や交流の障壁となる場合もあり、丁寧な対応 が必要であることも強く認識される必要がある。

\section{VIおわりに}

以上、本稿は、文科省「戦略的環境リーダー育 成拠点形成事業」における各大学の取組に着目 し、実施組織体制面から全学的連携と実践継続に ついて、教育実践面から ESDに求められる特性 の実現について、可能性と課題を整理し、大学の ESD 進展へ向けて鍵となる観点を示し考察した。

本事業と「ESDの10年」はともに終了間近だが、 大学におけるESDの実現は緒に就いたばかりで ある。これまでの取組が実質的なESD として発 展し、継続し、広がるかは、今後の取組次第とい える。本稿はその一歩を導く道標を示すことを目 指したが、さらに今後、各実践の関係者らへの聞 取り等を含め、成果と課題に対する詳細な検証が なされ、それにもとづく推進策が具体化すれば、 大学において、実践にもとづく ESDの推進が実 現するであろう。

※本研究はJSPS科研費 25560070 の助成を受けた。

\section{注}

(1)「国連持続可能な開発のための教育の10年」 関係省庁連絡会議，2011，『我が国における 「国連持続可能な開発のための教育の10年」 実施計画（E S D 実施計画）（平成 23 年 6 月 3 日改訂版)』, http://www.env.go.jp/press/ file_view. php?serial $=17664 \&$ hou $\mathrm{id}=13859$ (2013年10月 22 日アクセス). 
(2) 本稿では、国内で広く普及している「ESD (education for sustainable development 略)」の語を用いている。これは主に「持続 可能な開発のための教育」と訳されるが、国 際的には「持続可能性へ向けた教育」 (education for sustainability: EfS) もほほ同 義の語として盛んに使用されている。本稿で も日本語表記については「持続可能な開発」 ではなく「持続可能性」を統一的に用いるこ ととする。

（3）文科省, 2007, 現代 GP の審査と選定, http://www.mext.go.jp/a_menu/koutou/ kaikaku/gp/005.htm（2013 年10月 22 日アク 七ス)

(4)『長期戦略指針「イノベーション 25 」』、 2007、http://www.kantei.go.jp/jp/ innovation/saishu/070601/kakugil.pdf (2013 年 10 月 22 日アクセス)

(5) 総合科学技術会議、2008、『科学技術外交の 強化に向けて（案）平成 20 年 5 月 19 日』、 http://www8.cao.go.jp/cstp/siryo/haihu75/ siryo5-2.pdf（2013年 9 月 16 日アクセス）

(6) 文科省「戦略的環境リーダー育成拠点形成」 公募要領 http://www.jst.go.jp/shincho/ 20koubo/youryou/y40851.pdf（2008年度）、 http://www.jst.go.jp/shincho/21koubo/ youryou/y441.pdf (2009 年度)、http:// www.jst.go.jp/ shincho/22koubo/youryou/ $\mathrm{y} 451 . p d f （ 2010$ 年度）（いずれも2013年 10 月 22 日アクセス)

(7) 各採択大学の実施計画書・中間報告書は科学 技術振興機構ウェブサイトで公開されている http://www.jst.go.jp/shincho/program/ kankyou.html（2013年10月 22 日アクセス）

\section{引用文献}

阿部治, 2009,「『持続可能な開発のための教育』 （ESD）の現状と課題」, 『環境教育』19(2), 21-30.

阿部治監修・荻原彰編著, 2011, 『高等教育と ESD : 持続可能な社会のための高等教育』, 大
学教育出版, 岡山.

Clover, D. E. 1996, 'Developing international adult education: the challenge, theory and practice' , L. Filho, Z. Murphy and K. O' Loan, (ed.) A Sourcebook for environmental education: A practical review based on the Belgrade Charter. The Parthenon Publishing Group, London, 92-111.

Corcoran, P. B. and Wals, A. E. J. (Eds), 2004, Higher Education and the Challenge of Sustainability: Problematics, Promise, and Practice, Kluwer Academic Publishers. 2004

Dam-Mieras, R.V., 2006 , Learning for Sustainable Development: Is it Possible within the Established Higher Education Structure?, Holmberg, J. and Samuelsson, B.E., (eds), Drivers and Barriers for Implemnting Sustainable Development in Higher Education, UNESCO.

Escrigas, C. 2012, Foreword: Sustainability and Knowledge in Contemporary Society, Global University Network for Innovation (ed.), Higher Education in the World 4 - Higher Education's Commitment to Sustainability: from Understanding to Action, Palgrave Macmillan.

ESD-J（NPO法人「持続可能な開発のための教 育の 10 年」推進会議），2009，『わかる！ESD テキストブック 2 実践編 : 希望への学びあい 一なにを、どう、はじめるか一』, ESD-J.

Fien, J. and Skoien, P. 2002, 'I’ m learning ... How you go about stirring things up in a consultatie manner' : social capital and action competence in two community catchment groups' , Local Environment, 7 (3), 269-282.

降旗信一, 2006, 「序章 自然体験学習とは何か」, 降旗信一・朝岡幸彦編著『自然体験学習論〜豊 かな自然体験学習と子どもの未来（「子どもと おとなのための環境教育」シリーズ 2 )』, 高文 堂出版, 東京, 15-40.

Granados-Sanchez, J., Wals, A.E.J., Ferrer-Balas,

D., Waas, T., Imaz, M., Nortier, S., Svanstrom M., Land, H.V., and Arriaga, G., 2012 , 
Sustainability in Higher Education: Moving from Understanding to Action, Breaking Barriers for Transformation, Global University Network for Innovation (ed.), Higher Education in the World 4 - Higher Education's Commitment to Sustainability: from Understanding to Action, Palgrave Macmillan, 193-207.

原田泰, 2009,「日本での ESD の理論研究の可能 性」, 『環境教育』, 19(2), 31-32.

櫃本真美代, 2009, 「地元学に学ぶ地域づくりに 向けた環境教育の一考察一東北タイ・ブア村の 事例から一」, 『環境教育』, 18(3), 15-26.

比屋根哲, 2009, 「大学教育と $\mathrm{ESD} 」$, 『環境教育』, 18 (3) : 68-72.

Kato, K. 2002 , Environment and culture:

Developing alternative perspectives in environmental discourse, Canadian Journal of Environmental Education, Vol. 7(1), 110-116.

小玉敏也・阿部治, 2006,「『持続可能な開発のた めの教育』に向けた環境教育における『参加型 学習』概念の検討」, 『環境教育』15(2): 45-55.

Komiyama, H., Takeuchi, K., Shiroyama, H. and Mino, T., (eds.), 2011, Sustainability Science: A Multidisciplinary Approach, United Nations University Press.

Marouli, C. 2002, Multicultural Environmental Education: Theory and Practice, Canadian Journal of Environmental Education, 7(1), 26-42.

Martin, S., Dawe, G. and Jucker, R., 2006 , Embedding Education for Sustainable Development In Higher Education in the UK, Holmberg, J. and Samuelsson, B.E., (eds), Drivers and Barriers for Implemnting Sustainable Development in Higher Education, UNESCO.

見上一幸, 2009,「ESDをめぐる環境教育 : 地域 における ESD活動の立場から」, 『環境教育』, 19(2): 33-34.

Mino, T., and Hanaki, K. (eds), Environmental Leadership Capacity Building in Higher Education: Experience and Lessons from Asian Program for
Incubation of Environmental Leaders, Springer Open.

中川光弘, 2010,「大学における環境人材教育一茨 城大学の試み一」『共生社会システム学会 共 生社会システム研究 Vol.4, No.1：環境共生社会 創造のための教育・人づくり』, 29-41.

日本学術会議環境学委員会環境思想 - 環境教育分 科会, 2008, 「日本学術会議提言『学校教育を 中心とした環境教育の充実に向けて』」、環境 教育』, 18 (2) : 60-67.

二ノ宮リムさち, 2013a,「大学の環境人材育成に おける「現場のための教育」の可能性と課題一 持続可能な社会づくりへ向けた大学院教育を実 現する「現場体験」とは」『共生社会システム 研究』7(1), 137-157.

二ノ宮リムさち，2013b，「ESDにおける住民＝ 学習者の主体性と地域開発政策への位置づけ一 『わかりにくい』ESDを乗り越える地域の実践 と unlearn とは一」, 『ESD研究』9, 62-70.

二ノ宮リムさち・古市剛久 ·下ヶ橋 雅樹 - 尾崎 宏和, 2013,「エネルギー問題と向き合う環境 教育を日本から推進する一国内外の大学院生と 教員がエネルギーの地産地消をともに学ぶ試み から」,『環境教育』22(2), 82-89.

新田和宏, 2003, 「持続可能な社会を創る環境教 育」, 『持続可能な開発のための学び』, 開発教 育協会, 22-30.

Nomura, K. and Abe, O., 2010, Higher Education for Sustainable Development in Japan: Policy and Progress, International Journal of Sustainability in Higher Education, 11 (2), 120-129. 野村康·太田絵里・高橋正弘, 2010, 「高等教育 における ESD : 研究の現状と課題」, 『環境教 育』, 20(1)：25-34.

荻原彰，2011，「第4章 高等教育における ESD 一今後の展望一」, 阿部治監修・荻原彰編著『高 等教育と ESD : 持続可能な社会のための高等 教育』, 大学教育出版, 岡山, 134-161.

Proudman, B. 1992, Experiential education as emotionally-engaged learning, Journal of Experiential Education, 15(2), 19-23. 
Ryan, A., Tilbury, D., Corcoran, P.B., Abe, O. and Nomura, K., 2010, Sustainability in higher education in the Asia-Pacific: developments, challenges, and prospects, International Journal of Sustainability in Higher Education, 11 (2), 106119.

Sauve, L. 1998, Environmental Education between Modernity and Postmodernity: Searching for an Integrating Educational Framework, A. Jarnet, B. Jickling, L. Sauve, A. Wals, and P. Clarkin (eds), $2000, a$ colloquium on The Future of Environmental Education in a Postmodern World, Proceedings of an on-line colloquium held Oct. 19, 1998, Canadian Journal of Environmental Education, Yukon, 37-56.

Stein D. S. and Imel, S., 2002, Adult learning in community: Themes and threads, New directions for adult and continuing education, 95, Fall, 93-97.

高橋正弘・吉沢麻衣子, 2008 , 「大学が環境人材 の育成に取組む際の教訓の析出一国内大学への 質問紙調査を通してー」,『環境システム研究論 文発表会講演集』36巻, 167-172.

Tamura, M. and Uegaki, T., 2012, Development of an educational model for sustainability science: challenges in the Mind-SkillsKnowledge education at Ibaraki University, Sustainability Science, 7 (2), 253-265.

辻村真貴, 2013,「環境リーダープログラムの今後 の展望と課題一 1000 人の環境リーダー人材ネッ トワークをどのように生かしていくべきか一」, 『環境リーダープログラム合同会議 2013 ：予稿 集』, 筑波大学EDL 事務局.

筑波大学EDL 事務局, 2013, 『環境リーダープロ グラム合同会議 2013 : 予稿集』.

Tilbury, D., 2012, Higher Education for

Sustainability: A Global Overview of Commitment and Progress, Global University Network for Innovation (ed.),

Higher Education in the World 4 - Higher
Education's Commitment to Sustainability: from Understanding to Action, Palgrave Macmillan. Tilbury, D., and K. Cooke. 2005. A national review of environmental education and its contribution to sustainability in Australia: Frameworks for sustainability. Canberra: Australian Government Department of the Environment and Heritage and Australian Research Institute in Education for Sustainability (ARIES).

UNESCO, 2003, United Nations Decade of Education for Sustainable Development (January 2005 - December 2014): Framework for a draft international implementation scheme (Draft).

UNESCO. 2005. International Implementation Scheme (IIS) for the DESD. (佐藤・阿部監訳, 2006, 「国連持続可能な開発のための教育の 10 年国際実施計画 (日本語訳) 」, 『ESD-J2005 活 動報告書』, 持続可能な開発のための教育の 10 年推進会議, 173-193. )

UNESCO, 2006, Framework for the UNDESD International Implementation Scheme, ED/ DESD/2006/Pl/1.

UNESCO, 2012, Shaping the Education of Tomorrow: 2012 Report on the UN Decade of Education for Sustainable Development, Abridged.

Wals, A.E.J. and Blewitt, J. 2010. Third-wave sustainability in higher education: some (inter)national trends and developments. Jones, P., Selby, D., and Sterling, S. (ed.) Sustainability Education: Perspectives and practice across higher education. London: Earthscan, p. 55-74.

Wright, T., 2004, The Evolution of Sustainability Declarations in Higher Education, Corcoran, P.B. and Wals, A.E.J. (eds.), Higher Education and the Challenge of Sustainability: Problematics, Promise, and Practice, Kluwer Academic Publishers. 